\title{
Breast reconstruction and radiotherapy: a literature review
}

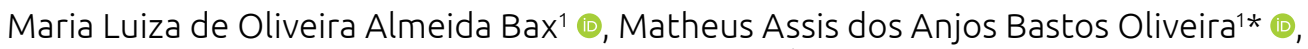

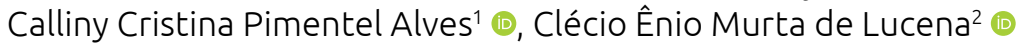

\section{ABSTRACT}

Breast cancer is the most common malignancy in women worldwide. After mastectomy, many women wish to reconstruct the affected breast and immediate breast reconstruction has been proven oncologically safe compared to mastectomy only. In addition, indications for post-mastectomy radiotherapy (PMRT) sessions are becoming more frequent, due to their relationship with reduced mortality and locoregional recurrence. For this reason, many women who opted for immediate reconstruction underwent radiotherapy with implants or expanders. The objective of this study was to compare the outcome of patients with breast cancer undergoing adjuvant radiotherapy after breast reconstruction with an implant or expander with that of patients who did not need irradiation. A literature review was carried out on the CAPES Journal Portal. The studies are unanimous when it comes to the increased risk of complications between control groups and patients who have undergone PMRT. Reconstruction failure rates were lower and the esthetic results were better in surgeries with implants compared with tissue expanders. Autologous surgeries are apparently safe and should be considered in the context of PMRT. This review did not find sufficient scientific evidence to determine the best technique and the best period for radiotherapy in PMRT indications. The choice of the surgical technique and the time of radiotherapy must be at the discretion of the surgeon and multidisciplinary team of each service, always in a shared decision with the patient.

KEYWORDS: breast cancer; mammaplasty; breast implants; radiotherapy, adjuvant; surgical flaps.

\section{INTRODUCTION}

Breast cancer is one of the most common malignancies in women and one of the three most common cancer types worldwide. Most women that undergo mastectomy are candidate for reconstruction of the mutilated breast, either immediately or at a later moment. Immediate breast reconstruction, that is, performed at the same time as the mastectomy, has been proven safe from an oncological point of view when considering local recurrence and long-term survival. In addition, the psychological, self-esteem, financial and esthetic benefits compared to other procedures should be taken in consideration.

As a general rule, two techniques using heterologous materials are widely used in immediate reconstructions (breast prostheses or implants and tissue expanders). The first one is the implant itself, the other is a two-step reconstruction in which a tissue expander is implanted during mastectomy (step 1), its expansion is performed during the postoperative period and, later, the permanent implant is inserted (step 2).
Referrals for post-mastectomy radiotherapy (PMRT) sessions have become more frequent due to their relation with reduced mortality and locoregional recurrence in women with breast cancer. The referral to radiotherapy is not a routine, and a set of information including data on pathological anatomy and other histopathological parameters is necessary for a more assertive diagnosis and management. Thus, many women with an indication for immediate heterologous breast reconstruction underwent adjuvant radiotherapy in implants or expanders that had already been inserted.

This work aims to analyze and discuss, through a review of the recent literature, the effects and outcomes of radiotherapy in women who underwent heterologous breast reconstruction immediately after mastectomy.

\section{OBJECTIVES}

To compare the outcomes of patients with breast cancer undergoing adjuvant radiotherapy after breast reconstruction with definitive implant or tissue expander with that of patients who had no indication for adjuvant radiotherapy.

1 Universidade Federal de Minas Gerais - Belo Horizonte (MG), Brazil.

Department of Gynecology and Obstetrics, Universidade Federal de Minas Gerais - Belo Horizonte (MG), Brazil.

*Corresponding author: matheus.bastos.oliveira46@gmail.com

Conflict of interests: nothing to declare.

Received on: 10/16/2021. Accepted on: 12/08/2021. 


\section{METHODS}

\section{Selection - inclusion and exclusion criteria}

All studies addressing the outcome of patients with breast cancer undergoing or not adjuvant radiotherapy after breast reconstruction surgery with an implant or tissue expander were considered, whether performed in one or two stages. Studies that considered only autologous augmentation were also used with the purpose of comparison and enrichment of this paper.

\section{Database}

The search was carried out in the PubMed database and Capes Journal Portal.

\section{Descriptors}

The descriptors used were: Postmastectomy Radiotherapy AND implant-based reconstruction; Postmastectomy Radiotherapy AND TRAM; Postmastectomy Radiotherapy AND latissimus dorsi.

\section{Time limit and language}

Articles published between 2014 and 2020 in English and Portuguese were selected.

\section{Research phases}

We found 128 articles during the research, then we did an exploratory reading. As a result, we selected 42 articles for selective reading and 18 articles were finally chosen as matching the goals and subjects of this study; analytical reading and analysis of texts, with interpretative reading, compilation of relevant results and, finally, writing (Figure 1).

\section{RESULTS}

The definition of reconstruction failure mentioned in the articles was permanent removal of the tissue expander (TE) or permanent implant (PI) without replacement or conversion to autologous augmentation or secondary absence of breast reconstruction ${ }^{1}$.

Most of the results of the analyzed articles showed that the chances of failure in reconstructions are greater after a radiotherapy session, for those who used both a tissue expander or a permanent implant when compared with patients who underwent reconstruction and did not receive radiotherapy. These data support the relevance of a longitudinal and close follow-up of these patients, since PMRT is still the standard adjuvant therapy for patients who opted for immediate breast reconstruction with an implant ${ }^{2}$.

When comparing PMRT for patients that underwent breast reconstruction with a tissue expander versus PMRT with a permanent implant, Cordeiro et al. demonstrated that radiation on tissue expanders increased the rate of failures and complications compared to permanent implants ( $32 \%$ versus $16.4 \%$ in six years of follow-up; $\mathrm{p}<0.01)$. On the other hand, esthetic results and satisfaction with the reconstruction were higher among patients who exchanged the tissue expander for the definitive implant after radiotherapy3.

Another study came to the same conclusion as above, but stating that patients with a history of depression had a significant increase in complication rates for both tissue expanders and permanent implants ${ }^{4}$.

Furthermore, when comparing non-irradiated patients with patients undergoing tissue expander radiotherapy or permanent implant radiotherapy, the reconstruction failure rate is significantly lower among non-irradiated women, with a reduction of $5.5 \%(\mathrm{p}<0.01)^{3}$.

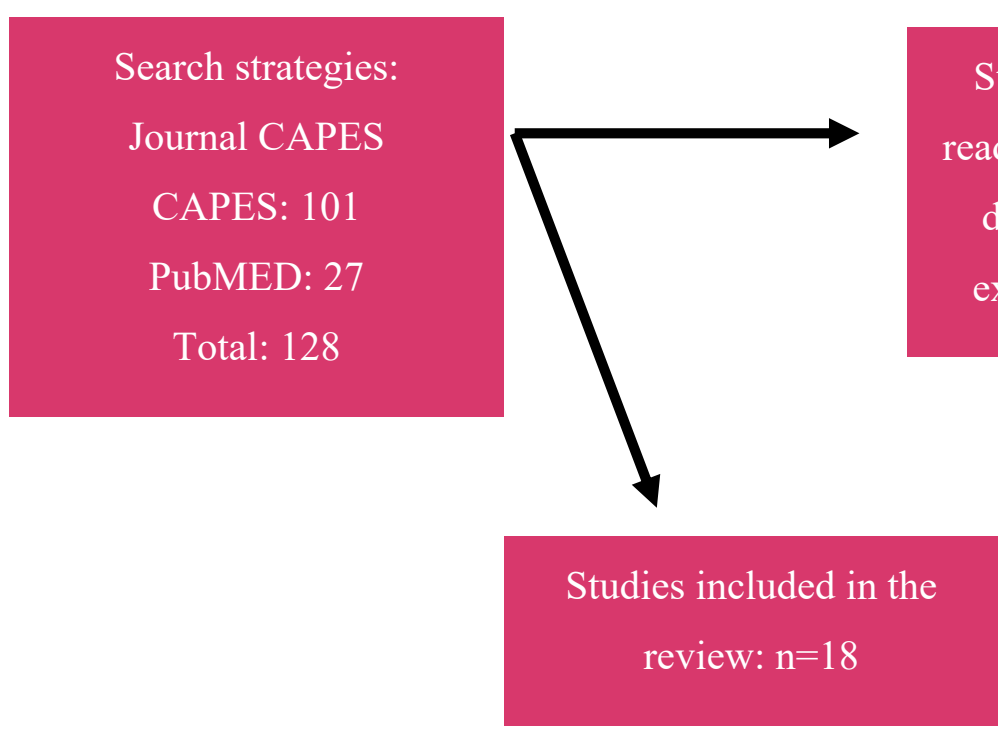

Figure 1. Descriptive flowchart of selection process. 
The pathogenesis of capsular contracture is not well understood. It is a multifactorial process that involves a reaction in the human body, with the formation of a biofilm, and also a possible colonization of the implant by bacteria ${ }^{5}$.

Moreover, patients that underwent radiation on tissue expanders had a better proportion of good esthetic outcomes compared to patients with permanent implants $(75.0 \%$ versus $67.6 \%$; $p<0.01)$ and lower rates of grade IV capsular contracture $(p<0.01)$, which is considered severe and indicates an unacceptable result and/or painful symptomatology, requiring new surgical intervention ${ }^{3,5}$.

Patients that did not have any reconstructive failures had varied proportions of capsular contracture according to the type of procedure adopted after mastectomy: grade III capsular contracture was present in $3.7 \%$ of implants without radiotherapy; $15.9 \%$ of patients who received radiotherapy with tissue expander; and $44.6 \%$ of patients who received radiotherapy with permanent implant $(\mathrm{p}<0.01)$. Grade IV capsular contracture was present in $0.4 \%, 1.22 \%$ and $6.3 \%$ of the groups mentioned, respectively ${ }^{3}$.

In another study, Barry and Kell ${ }^{6}$ demonstrated that immediate implant reconstruction in patients who received radiotherapy have a significantly higher incidence of complications compared to those who did not receive radiotherapy. This is not surprising, as radiotherapy treatment can affect the esthetic result and cause an increase in postoperative complications, in addition to having its effectiveness impaired when done immediately after breast reconstruction.

According to Barry and Kell immediate breast reconstruction after skin sparing mastectomy offers a number of advantages over delayed reconstruction. Firstly, it provides better esthetic results due to the preservation of the infra-mammary fold and skin envelope, allowing for a more natural appearance and the possibility of adjusting the surgical scar position. In addition, for the patient, it restores femininity and improves vitality, sexuality and quality of life, while avoiding or recovering resulting depressive conditions.

In a recent study, Lam et al. analyzed, between 1998 and 2010, 452 patients who underwent immediate breast reconstruction in two stages, involving a total of 562 breasts. The first phase was defined as the insertion of temporary expander and, the second one, as the insertion of permanent implant. Postoperative adjuvant radiotherapy was recommended on the tissue expander in situ for 114 patients. Overall postoperative prosthesis loss was $2.7 \%$. For patients undergoing adjuvant chemotherapy, the loss was $5.3 \%$, increasing to $11.3 \%$ for patients receiving chemotherapy and radiotherapy. Chemotherapy and radiotherapy were the main risk factors, with a statistically significant result of loss of expander or breast implant; RR: $13.85(\mathrm{p}=0.012)$ and $2.23(\mathrm{p}=$ 0.027), respectively. Prosthesis loss for patients undergoing chemotherapy combined with radiotherapy was also significant; IRR: $4,791(\mathrm{p}<0.001)^{7}$.
Also from 2018, a meta-analytic study conducted in China by Pu et al., demonstrated that the use of PMRT increased the failure rate of breast implant reconstruction [odds ratio (OR): 2.59; 95\%CI 1.46-4.62; $\mathrm{p}=0.001]$. Heterogeneity was considered significant $\left[\mathrm{I} 2=73 \%, \chi^{2}=33.39(\mathrm{df}=9), \mathrm{p}=0.001\right]^{2}$.

When dealing with the technique of breast reconstruction with transversus abdominis muscle (TRAM) flap, Lee et al. compared the long-term results of PMRT among breast cancer patients with and without immediate myocutaneous flap reconstruction. A total of 492 patients were assessed, of which 213 underwent reconstruction with the TRAM technique. The results suggested that immediate reconstruction with TRAM flap does not compromise long-term clinical outcomes in breast cancer patients requiring PMRT. There was no statistically significant difference in rates of local recurrence, distant metastases, disease-free survival and overall survival when comparing immediate TRAM flap reconstruction with no reconstructions.

In contrast, Rochlin et al. compared the effect of PMRT on TRAM reconstruction. In a literature review, they evaluated the evidence from all fields involved in the care of patients with breast cancer, in order to advance a recommendation on this therapeutic sequence. Eleven retrospective studies with 337 patients with an average follow-up of 18-60 months were included. These authors found an increased probability of fat necrosis in the irradiated breast $(\mathrm{OR}=3.13,95 \% \mathrm{CI} 1.42-6.89, \mathrm{p}=0.005)$ in three studies with non-irradiated controls and five studies that evaluated the estheticoutcome with varying results. The final conclusion is that additional prospective studies are needed, since current evidence is contradictory9.

Regarding the technique of breast reconstruction using the latissimus dorsi myocutaneous flap, Carrabin et al. compared and evaluated the results of breast reconstruction with latissimus dorsi muscle without implant followed by adjuvant radiotherapy. Thirty-one patients with irradiated reconstructions performed between 1999 and 2013 were assessed. Two individuals died in the period. Breast reconstruction results were rated as very good or good in $86 \%$ of cases, with reconstructed breast consistency evaluated as very good or good in $93 \%$ of cases. The authors considered the technique had good tolerance to adjuvant irradiation and could be used in patients willing to benefit from immediate reconstruction and with an indication for subsequent radiotherapy ${ }^{10}$.

Following the technique of breast reconstruction with latissimus dorsi muscle, Yun et al. demonstrated that according to a systematic review of patients treated with PMRT with or without adjuvant chemotherapy from 2000 to 2015, there was a significantly higher weighted incidence of reoperation (37.0\% versus $16.6 \%$, p < 0.0001 ), global complications ( $41.3 \%$ versus $30.9 \%$, $<<$ $0.0001)$, and reconstructive failure ( $16.8 \%$ versus $1.6 \%, \mathrm{p}<0.0001)$ in patients undergoing breast reconstruction with definitive implants when compared to reconstruction with autologous 
material ${ }^{11,12}$. A single study comparing immediate latissimus dorsi flap with tissue expander reconstruction after mastectomy followed by PMRT found a trend of surgical wound complications requiring reoperation in the tissue expander group, concluding that immediate latissimus dorsi flap reconstruction is a viable and safe option for patients undergoing PMRT ${ }^{13}$. In the subset of patients who received pre-mastectomy total breast radiotherapy, studies show a significant increase in the risk of complications associated with the use of tissue expander-based reconstruction, and autologous or myocutaneous flap reconstruction is strongly recommended ${ }^{14,15}$.

A recent study by Chiasson et al. involved a two-phase approach using latissimus dorsi myocutaneous flaps and tissue expanders for immediate reconstruction after mastectomy, followed by replacement with implants in a secondary surgery. A retrospective review was performed on 201 medical records (376 breast reconstructions) of patients who met the inclusion criteria. Reconstructive success was defined as no need for additional autologous reconstruction beyond the two-stage approach. When analyzing the complications and final outcomes, there was no difference between non-irradiated and irradiated patients, except when reconstructive loss was observed (3.6\% rate in the non-irradiated group and $16.6 \%$ in the irradiated group, $p=0.03$ ). However, one third of the cases of reconstructive losses among patients in the irradiated group were due to reasons unrelated to radiotherapy. Taking this into account, overall reconstructive success was not statisticaly significant when comparing groups. The findings of this study show that immediate reconstruction with latissimus dorsi myocutaneous flaps in conjunction with prosthetic devices is reliable and safe even in the setting of adjuvant radiotherapy, as the autologous tissue attenuates many of the sequelae of radiotherapy itself. This type of reconstruction not only provides an esthetically pleasing two-stage outcome, but also has a favorable complication profile and a very acceptable success rate ${ }^{16}$.

A relatively simple procedure that is increasingly being recognized as a strategy in the irradiated patient is autologous lipotransfer or fat grafting. Regarding this technique, Ribuffo et al. apud Crawford and Endara presented a series of 32 patients who underwent modified radical mastectomy followed by radiotherapy. The patients were immediately reconstructed with placement of a tissue expander in the submuscular plane. Half of the patients underwent one or two procedures complemented with autologous lipotransfer six weeks after the completion of radiotherapy, before exchanging the expander for the definitive implant. There was a $0 \%$ complication rate in the treated group and a $43 \%$ rate in the control group. The introduction of lipotransfer as a separate but necessary procedure within the protocol was unique and became a formal piece and fundamental factor for the success of this procedure ${ }^{17,18}$.
Another study by Serra-Renom et al. apud Crawford and Endara confirmed the usefulness of lipotransfer in 65 irradiated and mastectomized patients, incorporating serial fat grafts in their protocol. These patients underwent multiple fat grafting procedures, before and at the time of exchanging the expander with the implant, with excellent clinical results. This study had limitations, as patients were not demonstrating significant acute effects of radiation in the form of radiodermatitis and, therefore, the severity of tissue damage was in question ${ }^{17,19}$.

In a systematic review, Oliver et al. gathered 11 studies with data from 1,565 procedures for immediate breast reconstruction (IBR) with a double-stage expander, where PMRT was employed. Of the total, 1,145 were irradiated before replacement of the tissue expander and 420 were irradiated after inclusion of the definitive implant. There was a statistically significant higher probability of surgical bed infection with the addition of radiotherapy before permanent implant placement (21.03\%, $\mathrm{p}=0.000079$ ), compared with PMRT after implant placement $(9.69 \%)$.There was no significant difference in the explantation rate between PMRT performed before definitive implant placement (12.93\%) compared to those who performed PMRT after definitive implant placement $(11.43 \%)^{20}$. A retrospective study ${ }^{21}$ evaluated 4,068 patients in a prospectively collected database that included 2,284 patients, or 3,489 breasts, who met the study's inclusion criteria. Most patients had bilateral reconstruction $[\mathrm{n}=1,215(53.5 \%)]$ with silicone implants [n $=1,244(54.5 \%)]$. Three hundred twenty-three patients (14\%) underwent some form of radiation therapy as part of their breast cancer treatment. Eighty-seven patients (3.8\%) underwent radiotherapy before reconstruction, and the remainder underwent adjuvant radiation therapy of their tissue expanders $[\mathrm{n}=43(1.9 \%)]$ or permanent implant $[\mathrm{n}=193(8.4 \%)]$. Esthetic outcomes over time were compared and evaluated for patients over a 12-year period. Patients were then subdivided to analyze long-term trends into distinct reconstructive groups. In general, patients with bilateral reconstructions had significantly higher esthetic scores compared to unilateral reconstruction, and this trend continued over time ( $\mathrm{p}<0.001)$. Further comparison of patients undergoing or not radiotherapy had a similar consistency, with better esthetic ratings between non-irradiated than bilateral irradiated reconstructions over the first 9 years of follow-up $(\mathrm{p}<0.05)$. Unilaterally irradiated reconstructions had lower esthetic scores among all patients during the full 12-year follow-up period $(\mathrm{p}<0.05)$. Capsular contracture rates were assessed in all reconstructed breasts similarly between irradiated and non-irradiated patients. Irradiated and reconstructed breasts had higher rates of capsular contracture than non-irradiated breasts at all time points evaluated $(\mathrm{p}<0.001)$. Interestingly, both groups demonstrated the inflection point in the score, with a significant drop in mean scores for nonirradiated patients [1.38 (year 2) to 1.1 (year 3)] and also for 
irradiated patients [2.21 (year 3) to $1.82($ year 4$)](\mathrm{p}<0.05)$. These decreases in scores for capsular contracture were maintained for the remainder of the study follow-up period. The data visibly demonstrate the stability over time in the results reported by the surgeon regarding esthetic outcomes and the degree of capsular contracture following the technique of breast reconstruction based on breast implants. In the period from year 1 to year 12 of follow-up, scores for esthetic results between all techniques of bilateral reconstructions $(4.73 \pm 0.64$ to $4.44 \pm$ $0.82 ; \mathrm{p}<0.0001)$ and unilateral reconstructions $(4.02 \pm 0.91$ to $3.63 \pm 0.99 ; \mathrm{p}=0.0005$ ) had an overall decrease. Although these downward trends were statistically significant, because of the statistical power of individual groups, the clinical difference in scores ranged from 0.29 to 0.39 with overlapping confidence intervals. Likewise, the capsular contracture rate remained clinically and statistically stable throughout the study period for non-irradiated (year 1, $1.27 \pm 0.53$; year 12, $1.23 \pm 0.54$; $\mathrm{p}=$ 0.37 ) and irradiated breasts (year $1,1.92 \pm 0.89$; year 12 , 1.66 $\pm 0.87 ; \mathrm{p}=0.12$ ).

A subset analysis of all patients with outcome data reported and analyzed by the BREAST- $Q$ was performed based on breast irradiation status. Regarding satisfaction, non-irradiated patients reported significantly better results than irradiated patients during the first six years. On the other hand, when it comes to satisfaction with the overall results of the surgery, non-irradiated and irradiated patients showed no significant difference, except in the first year. A similar trend was observed by case reports of patients as to psychosocial and sexual well-being over time, with a normalization of scores between non-irradiated and irradiated patients after the first year of implant replacement. Physical well-being appears to mirror the trend of breast satisfaction, with non-irradiated patients scoring significantly higher than irradiated patients through year 6 , at which time scores among irradiated patients improved. Similarly to the stability observed in the results described by the surgeon over time, the patients' reports on the surgeries demonstrated visible stability in the scores, with an improvement over the same period. There was no overall worsening in patient-reported outcomes for any category measured over the 12-year study period. In particular, breast satisfaction and psychosocial well-being scores did not change. Satisfaction with the results increased significantly over time among all patients $(70.9 \pm 20.9$ versus $76.9 \pm 16.4 ; p=0.03)$, reaching the minimum important difference in the irradiated patients in year 1 to year 12 . Concerning sexual well-being, scores remained statistically similar over time; however, a comparison between year 1 and year 12 reached the minimum important difference among all patients. Meanwhile, physical well-being scores showed significant improvement (72.8 \pm 16.2 versus 82.8 \pm 15.5 ; $\mathrm{p}<0.0001)$ in non-irradiated $(74.1 \pm 15.9$ versus $83.2 \pm 15.4$; $\mathrm{p}=0.0002)$ and irradiated patients $(67.7 \pm 16.5$ versus $81.0 \pm 17.2$; $\mathrm{p}=0.02)^{21}$ (Table 1).

\section{DISCUSSION}

Most studies are retrospective, which conditions the results to the accuracy and availability of information. The assessment based on different characteristics and outcomes such as implant loss, capsular contracture and infection are objective and allow for a clearer view and a more detailed analysis of data. However, aspects such as esthetic results and satisfaction after surgery can be considered ambiguous and, therefore, potentially confusing factors.

The studies are unanimous when it comes to the increased risk of complications between control groups and patients undergoing PMRT. In all studies that considered patients with and without radiotherapy after breast reconstruction, the group undergoing PMRT had a higher rate of adversities ${ }^{4,7}$. Studies have showed no significant difference as for the timing of radiotherapy ${ }^{1}$.

As for the technique used, some studies compared permanent implants with tissue expanders, and the global reconstructive failure rates were lower and with better esthetic results in surgeries with definitive breast implants ${ }^{3}$. An important aspect identified in the literature is that in double-stage breast reconstruction with an indication for PMRT, irradiation after replacing the expander with the definitive implant has a lower overall failure rate but a higher rate of severe capsular contracture and worse esthetic results. On the other hand, irradiation of tissue expander and subsequent replacement with definitive implant presents a greater risk of reconstructive failure, but a lower rate of severe capsular contracture and a more favorable esthetic result.

Regarding other less used techniques such as TRAMflap andLDF, the literature lacks studies comparing the superiority between autologous techniques, however, they agree that both techniques are reliable, safe and reproducible when there is a need to perform PMRT ${ }^{8,10,14,16}$.

\section{CONCLUSION}

Despite the well-known importance of radiotherapy in the context of oncological indications for breast cancer, its impact on the various techniques and strategies for breast reconstruction in women undergoing mastectomy is undeniable. We found studies suggesting potential benefits for each technique used in breast reconstruction in patients with an indication for PMRT, suggesting specific and varying measures to reduce the occurrence of potential complications. In this review, we did not find enough scientific evidence to determine the best technique and the best sequencing for this purpose. Radiotherapy and Chemotherapy together significantly increase the rate of complications associated with breast reconstruction techniques. Moreover, in the double-phase reconstruction strategy with tissue expander along with PMRT, the timing of irradiation (before or after the exchange of the expander with the definitive implant) interferes with the overall failure rate of breast reconstruction, as well as other surgical complications.

In conclusion, the choice of the surgical technique and the timing of radiotherapy should be defined by the surgeon and the 
Table 1. Characteristics of studies.

\begin{tabular}{|c|c|c|c|c|c|c|}
\hline Author, year & Study Type & Approach & $\mathbf{n}$ & AT & Results & Conclusion \\
\hline $\begin{array}{l}\text { Ogita et al., } \\
2018^{1}\end{array}$ & Retrospective & $\begin{array}{l}\text { To evaluate } \\
\text { PMRT } \\
\text { complication } \\
\text { rates for tissue } \\
\text { expanders } \\
\text { versus } \\
\text { permanent } \\
\text { implant. }\end{array}$ & 81 & 32 & $\begin{array}{c}\text { Total reconstruction failure, } \\
\text { reoperation and infection rates } \\
\text { were } 12.3,13.6 \text { and } 11.1 \% \text {, } \\
\text { with } 5 \text {-year cumulative of } 16.7 \text {, } \\
16.6 \text { and } 12.2 \% \text {, respectively. }\end{array}$ & $\begin{array}{l}\text { There were no } \\
\text { significant differences } \\
\text { in complication rates } \\
\text { concerning the timing of } \\
\text { radiotherapy. Age over } \\
55 \text { years is a risk factor } \\
\text { for complications. }\end{array}$ \\
\hline $\begin{array}{l}\text { Cordeiro } \\
\text { et al., } 2015^{3}\end{array}$ & Retrospective & $\begin{array}{l}\text { Comparative } \\
\text { study of results } \\
\text { related to } \\
\text { reconstructive } \\
\text { failure, } \\
\text { aesthetic } \\
\text { results and } \\
\text { capsular } \\
\text { contracture } \\
\text { in patients } \\
\text { undergoing } \\
\text { PMRT with } \\
\text { expanders and } \\
\text { implants. }\end{array}$ & 1,790 & 108 & $\begin{array}{c}\text { 6-year failure rates higher in } \\
\text { patients with expanders ( } 32 \% \\
\text { versus } 16.4 \% ; p<0.01) \text {. } \\
\text { Patients undergoing PMRT } \\
\text { with expanders had a higher } \\
\text { proportion of very good to } \\
\text { excellent esthetic results ( } 75 \% \\
\text { versus } 67.6 \% \text {; } p<0.01 \text { ) and } \\
\text { lower rates of grade IV capsular } \\
\text { contracture }(p<0.01) \text {. }\end{array}$ & $\begin{array}{l}\text { The overall risk of } \\
\text { reconstructive failure } \\
\text { is significantly higher } \\
\text { for patients with tissue } \\
\text { expander irradiation } \\
\text { compared to patients } \\
\text { with definitive implant } \\
\text { irradiation. Esthetic } \\
\text { results and capsular } \\
\text { contracture rates are } \\
\text { slightly better when } \\
\text { the tissue expander is } \\
\text { irradiated. }\end{array}$ \\
\hline $\begin{array}{l}\text { Chuba } \\
\text { et al., } 2017^{4}\end{array}$ & Retrospective & $\begin{array}{l}\text { Investigation } \\
\text { of previous } \\
\text { risk factors in } \\
\text { implant and } \\
\text { tissue expander } \\
\text { surgeries with } \\
\text { PMRT. }\end{array}$ & 127 & 120 & $\begin{array}{c}\text { Complications were: Grade } \\
0 \text { (no complications; 43.9\%), } \\
\text { Grade } 1 \text { (tightening and/or } \\
\text { implant deviation or Grade II } \\
\text { Baker capsular contracture; } \\
\text { 30.9\%), Grade } 2 \text { (infection, } \\
\text { hypertrophic scar or incisional } \\
\text { necrosis; 9.8\%), Grade } 3 \text { (Baker } \\
\text { grade III capsular contracture, } \\
\text { wound dehiscence or imminent } \\
\text { implant exposure; } 5.7 \%), \text { Grade } \\
4 \text { (implant failure, implant } \\
\text { exchange or Baker grade IV } \\
\text { capsular contracture; } 9.8 \% \text { ). } \\
\text { Considering non-irradiated } \\
\text { breasts, there were two } \\
\text { cases (1.6\%) of Grade } 3 / 4 \\
\text { complications. Patients with } \\
\text { depression were more likely } \\
\text { to experience Grade } 3 \text { or } 4 \\
\text { complications (29.4\% versus } \\
\text { 13.2\%; }=0.01 \text { ). }\end{array}$ & $\begin{array}{l}\text { Higher rates of } \\
\text { reconstruction } \\
\text { complications are } \\
\text { expected in patients } \\
\text { receiving radiotherapy. } \\
\text { History of depression } \\
\text { was significantly } \\
\text { related to increase in } \\
\text { complication rates. }\end{array}$ \\
\hline $\begin{array}{l}\text { Lam et al., } \\
2018^{7}\end{array}$ & $\begin{array}{c}\text { Retrospective, } \\
\text { cohort }\end{array}$ & $\begin{array}{l}\text { Analysis of } \\
\text { complications } \\
\text { including } \\
\text { prosthesis } \\
\text { loss, seroma } \\
\text { and infection } \\
\text { in patients } \\
\text { undergoing } \\
\text { chemotherapy } \\
\text { and PMRT. } \\
\text { Esthetic results } \\
\text { assessed using } \\
\text { a four-point } \\
\text { scale. }\end{array}$ & 452 & 144 & $\begin{array}{l}\text { The overall postoperative loss } \\
\text { of prosthesis was } 2.7 \%, 5.3 \% \text { for } \\
\text { patients undergoing adjuvant } \\
\text { chemotherapy, increasing to } \\
11.3 \% \text { in patients receiving } \\
\text { both chemotherapy and } \\
\text { radiotherapy. Chemotherapy } \\
\text { and radiotherapy independently } \\
\text { were the main statistically } \\
\text { significant risk factors for } \\
\text { expander or implant loss } \\
\text { [incidence rate ratio, } 13.85 \\
\text { ( } p=0.012 \text { ) and } 2.23 \text { ( } p= \\
\text { 0.027), respectively]. Implant } \\
\text { loss for patients undergoing } \\
\text { chemotherapy combined } \\
\text { with radiotherapy was also } \\
\text { significant [incidence rate ratio, } \\
4.791 \text { ( } p<0.001)] \text {. }\end{array}$ & $\begin{array}{l}\text { PMRT doubles the } \\
\text { risk of prosthesis loss } \\
\text { compared to adjuvant } \\
\text { chemotherapy, but } \\
\text { it is an acceptable } \\
\text { option after breast } \\
\text { reconstruction with } \\
\text { immediate two- } \\
\text { stage prosthesis in } \\
\text { a multidisciplinary } \\
\text { environment. }\end{array}$ \\
\hline
\end{tabular}


Table 1. Continuation.

\begin{tabular}{|c|c|c|c|c|c|c|}
\hline Author, year & Study Type & Approach & n & AT & Results & Conclusion \\
\hline $\begin{array}{l}\text { Lee et al., } \\
2016^{8}\end{array}$ & Retrospective & $\begin{array}{l}\text { Analysis of } \\
\text { outcomes and } \\
\text { survival of } \\
\text { patients with } \\
\text { stage II or III } \\
\text { breast CA who } \\
\text { underwent } \\
\text { modified radical } \\
\text { mastectomy and } \\
\text { chemotherapy } \\
\text { followed by } \\
\text { PMRT. }\end{array}$ & 492 & $11-191$ & $\begin{array}{l}\text { The } 5 \text { - and } 10 \text {-year disease-free } \\
\text { survival rates were } 81 \% \text { and } 76 \% \\
\text { for the TRAM flap group and } \\
78 \% \text { and } 73 \% \text { for the non-flap } \\
\text { group. The } 5 \text { - and } 10 \text {-year overall } \\
\text { survival rates were } 89 \% \text { and } 73 \% \\
\text { for the TRAM flap group and } 83 \% \\
\text { and } 74 \% \text { for the non-flap group. }\end{array}$ & $\begin{array}{l}\text { No statistically significant } \\
\text { difference in rates of } \\
\text { local recurrence, distant } \\
\text { metastasis, disease- } \\
\text { free survival and overall } \\
\text { survival when comparing } \\
\text { immediate TRAM flap } \\
\text { reconstruction with } \\
\text { surgeries without } \\
\text { reconstruction. }\end{array}$ \\
\hline $\begin{array}{l}\text { Carrabin } \\
\text { et al., } 2015^{10}\end{array}$ & $\begin{array}{c}\text { Retrospective, } \\
\text { case-control }\end{array}$ & $\begin{array}{l}\text { Analysis of } \\
\text { esthetic } \\
\text { outcomes } \\
\text { of patients } \\
\text { operated } \\
\text { with the LDF } \\
\text { technique } \\
\text { undergoing } \\
\text { PMRT. }\end{array}$ & 87 & 78 & $\begin{array}{c}\text { The result of cosmetic } \\
\text { reconstruction was rated as } \\
\text { good or very good in } 86 \% \text { of the } \\
\text { cases, with the consistency of the } \\
\text { irradiated breast rated as good } \\
\text { or very good in } 93 \% \text { of the cases. } \\
\text { Complementary fat transfer was } \\
\text { performed on average } 11 \text { months } \\
\text { after radiotherapy in } 58 \% \text { of } \\
\text { cases. }\end{array}$ & $\begin{array}{l}\text { The LDF technique has } \\
\text { good tolerance for PMRT. }\end{array}$ \\
\hline $\begin{array}{l}\text { Chen et al., } \\
2016^{14}\end{array}$ & Retrospective & $\begin{array}{l}\text { Analysis of } \\
\text { complications } \\
\text { in patients } \\
\text { undergoing } \\
\text { immediate } \\
\text { breast } \\
\text { reconstruction } \\
\text { with expander } \\
\text { implants in } \\
\text { the context of } \\
\text { radiotherapy. }\end{array}$ & 76 & 72 & $\begin{array}{l}\text { The probability of developing } \\
\text { complications in patients in the } \\
\text { RXT-pre and RXT-post groups } \\
\text { were } 2.0 \text { and } 2.3 \text {, respectively. }\end{array}$ & $\begin{array}{l}\text { For patients who received } \\
\text { pre-mastectomy total } \\
\text { breast radiotherapy, } \\
\text { autologous augmentation } \\
\text { is strongly recommended. } \\
\text { The sub-analysis of the } \\
\text { pre-RXT group showed } \\
\text { a significantly higher } \\
\text { mean number of total } \\
\text { complications }\end{array}$ \\
\hline $\begin{array}{l}\text { Chiasson } \\
\text { et al., } 2020^{16}\end{array}$ & Retrospective & $\begin{array}{l}\text { Review of } \\
\text { the use of } \\
\text { the LD flap in } \\
\text { conjunction } \\
\text { with prosthetic } \\
\text { devices, } \\
\text { regardless } \\
\text { of the need } \\
\text { for adjuvant } \\
\text { radiation, to } \\
\text { determine } \\
\text { the safety and } \\
\text { effectiveness of } \\
\text { this approach } \\
\text { as a primary } \\
\text { reconstruction } \\
\text { method. }\end{array}$ & 201 & - & $\begin{array}{l}\text { There was no difference } \\
\text { between non-irradiated and } \\
\text { irradiated patients, except for } \\
\text { reconstructive loss, which was } \\
\text { 3.6\% in the non-irradiated group } \\
\text { and } 16.6 \% \text { in the irradiated group } \\
\text { ( } p=0.03) \text {. } \\
\text { However, one third of irradiated } \\
\text { patients had reconstructive } \\
\text { loss for reasons unrelated to } \\
\text { radiotherapy. }\end{array}$ & $\begin{array}{l}\text { The immediate } \\
\text { reconstruction with } \\
\text { LDF in conjunction with } \\
\text { prosthetic devices is a } \\
\text { reliable and safe option, } \\
\text { even in the context of } \\
\text { adjuvant radiotherapy, } \\
\text { as autologous tissue } \\
\text { attenuates many } \\
\text { radiotherapy injuries. }\end{array}$ \\
\hline
\end{tabular}

LDF: latissimus dorsi flap; PMRT: Post-mastectomy radiotherapy; post-RXT: external beam radiotherapy performed after surgery; pre-RXT: external beam radiotherapy performed before surgery; TE: Tissue expander; TRAM: Rectus abdominis flap. AT: average time (months)

multidisciplinary team of each service in a shared decision with the patient, emphasizing that depending on the choice, we may have a higher overall failure rate in the reconstruction, but on the other hand, the quality of the final esthetic results could be better. This review acknowledges the need for further prospective randomized comparative studies between the different techniques and strategies for breast reconstruction in patients who are candidate for mastectomy and breast reconstruction and with an indication for PMRT, so as to build better scientific evidence to support decision-making.

\section{AUTHORS' CONTRIBUTION}

M.L.O.A.B.: writing - revision \& editing, investigation, project administration, supervision, writing - original draft. M.A.A.B.O.: writing - revision \& editing, investigation, project administration, supervision, writing - original draft. C.C.P.A.: writing - review \& editing, investigation, project administration, supervision, writing - original draft. C.Ê.M.L: writing - revision \& editing, formal analysis, investigation, project administration, supervision, writing - original draft. 


\section{REFERENCES}

1. Ogita M, Nagura N, Kawamori J, In R, Yoshida A, Yamauchi $\mathrm{H}$, et al. Risk factors for complications among breast cancer patients treated with post-mastectomy radiotherapy and immediate tissue-expander/permanent implant reconstruction: a retrospective cohort study. Breast Cancer. 2018;25(2):167-75. http://doi.org/10.1007/s12282-017-0808-6

2. PuY,MaoTC,ZhangYM,WangSL,FanDL.Theroleofpostmastectomy radiation therapy in patients with immediate prosthetic breast reconstruction: a meta-analysis. Medicine (Baltimore). 2018;97(6):e9548. http://doi.org/10.1097/MD.0000000000009548

3. Cordeiro PG, Albornoz CR, McCormick B, Hudis CA, Hu Q, Heerdt A, et al. What is the optimum timing of postmastectomy radiotherapy in two-stage prosthetic reconstruction: radiation to the tissue expander or permanent implant? Plast Reconstr Surg. 2015;135(6):1509-17.http://doi.org/10.1097/PRS.0000000000001278

4. Chuba PJ, Stefani WA, Dul C, Szpunar S, Falk J, Wagner R, et al. Radiation and depression associated with complications of tissue expander reconstruction. Breast Cancer Res Treat. 2017;164(3):641-7. http://doi.org/10.1007/s10549-017-4277-6

5. Lucena CEM, Paulinelli RR, Pedrini JL. Oncoplastia e reconstrução mamária. Rio de Janeiro: Medbook; 2017.

6. Barry M, Kell MR. Radiotherapy and breast reconstruction: a meta-analysis. Breast Cancer Res Treat. 2011;127(1):15-22. http://doi.org/10.1007/s10549-011-1401-x

7. Lam TC, Borotkanics R, Hsieh F, Salinas J, Boyages J. Immediate two-stage prosthetic breast reconstruction failure: radiation is not the only culprit. Plast Reconst Surg. 2018;141(6):1315-24. http://doi.org/10.1097/PRS.0000000000004358

8. Lee HH, Hou MF, Wei SY, Lin SD, Luo KH, Huang MY, et al. Comparison of long-term outcomes of postmastectomy radiotherapy between breast cancer patients with and without immediate flap reconstruction. PLoS One. 2016;11(2):e0148318. http://doi.org/10.1371/journal.pone.0148318

9. Rochlin DH, Jeong AR, Goldberg L, Harris T, Mohan K, Seal S, et al. Postmastectomy radiation therapy and immediate autologous breast reconstruction: integrating perspectives from surgical oncology, radiation oncology, and plastic and reconstructive surgery. J Surg Oncol. 2015;111(3):251-7.http://doi.org/10.1002/jso.23804

10. Carrabin N, Vermersh C, Faure C, Dammacco MA, Delay E, Ho Quoc C. Tolérance du lambeau de grand dorsal sans prothèse à la radiothérapie en reconstruction mammaire immédiate. Annales de Chirurgie Plastique Esthétique. 2015;60(6):500-5. http://doi.org/10.1016/j.anplas.2015.05.005

11. Yun JH, Diaz R, Orman AG. Breast reconstruction and radiation therapy. Cancer Control. 2018;25(1):1073274818795489. http:// doi.org/10.1177/1073274818795489
12. El-Sabawi B, Sosin M, Carey JN, Nahabedian MY, Patel KM. Breast reconstruction and adjuvant therapy: a systematic review of surgical outcomes. J Surg Oncol. 2015;112(5):458-64. http://doi.org/10.1002/jso.24028

13. Durkan B, Amersi F, Phillips EH, Sherman R, Dang CM. Postmastectomy radiation of latissimus dorsi myocutaneous flap reconstruction is well tolerated in women with breast cancer. Am Surg. 2012;78(10):1122-7. http://doi. org/10.1177/000313481207801025

14. Chen TA, Momeni A, Lee GK. Clinical outcomes in breast cancer expander-implant reconstructive patients with radiation therapy. J Plast Reconstr Aesthet Surg. 2016;69(1):1422. http://doi.org/10.1016/j.bjps.2015.08.032

15. Lee KT, Mun GH. Prosthetic breast reconstruction in previously irradiated breasts: a meta-analysis. J Surg Oncol. 2015;112(5):468-75. http://doi.org/10.1002/jso.24032

16. Chiasson KF, Kumbla PA, Restrepo RD, Soto E, Cohn AB. Immediate latissimus dorsi and prosthetic reconstruction in the setting of postmastectomy radiation: an analysis of 376 breast reconstructions. Ann Plast Surg. 2020;84(6S Suppl 5):S364-8. http://doi.org/10.1097/SAP.0000000000002279

17. Crawford K, Endara M. Lipotransfer strategies and techniques to achieve successful breast reconstruction in the radiated breast. Medicina (Kaunas). 2020;56(10):516. http://doi. org/10.3390/medicina56100516

18. Ribuffo D, Atzeni M, Guerra M, Bucher S, Politi C, Deidda M, et al. Treatment of irradiated expanders: protective lipofilling allows immediate prosthetic breast reconstruction in the setting of postoperative radiotherapy. Aesth Plast Surg. 2013;37(6):1146-52. http://doi.org/10.1007/s00266-013-0221-2

19. Serra-Renom JM, Muñoz-Olmo JL, Serra-Mestre JM. Fat grafting in postmastectomy breast reconstruction with expanders and prostheses in patients who have received radiotherapy: formation of new subcutaneous tissue. Plast Reconstr Surg. 2010;125(1):12-8. http://doi.org/10.1097/ PRS.0b013e3181c49458

20. Oliver JD, Boczar D, Huayllani MT, Restrepo DJ, Sisti A, Manrique OJ, et al. Postmastectomy Radiation Therapy (PMRT) before and after 2-stage expander-implant breast reconstruction: a systematic review. Medicina (Kaunas). 2019;55(6):226. http://doi.org/10.3390/medicina55060226

21. Seth AK, Cordeiro PG. Stability of long-term outcomes in implant-based breast reconstruction: an evaluation of 12-year surgeon- and patient-reported outcomes in 3489 nonirradiated and irradiated implants. Plast Reconstr Surg. 2020;146(3):47484. http://doi.org/10.1097/PRS.0000000000007117 